\title{
Functional Characterization of Three Intercalated Cell Subtypes in the Rabbit Outer Cortical Collecting Duct
}

\author{
Cheryl Emmons ** and Ira Kurtz* \\ Nephrology Division, Department of Medicine, ${ }^{*}$ Wadsworth Veterans Administration Medical Center, Los Angeles, California $90024 ;$ and \\ ${ }^{\ddagger}$ University of California at Los Angeles Center for the Health Sciences, Los Angeles, California 90024
}

\begin{abstract}
The distribution of $\mathrm{Na}^{+}$-independent $\mathrm{Cl}^{-}-\mathrm{HCO}_{3}^{-}$exchange was studied in individual intercalated cells from in vitro perfused rabbit outer CCDs using dual excitation laser scanning confocal microscopy by measuring the $\mathrm{pH}_{\mathrm{i}}$ response to sequential removal of $\mathrm{Cl}^{-}$from both sides of the tubule. Three patterns of intracellular $\mathrm{pH}\left(\mathrm{pH}_{\mathrm{i}}\right)$ response were observed. $39 \%$ of intercalated cells had only apical $\mathrm{Cl}^{-}-\mathrm{HCO}_{3}^{-}$exchange ( $\beta$ cell), $4 \%$ had only basolateral $\mathrm{Cl}^{-}-\mathrm{HCO}_{3}^{-}$exchange ( $\alpha$ cell), and $57 \%$ had both apical and basolateral $\mathrm{Cl}^{-}-\mathrm{HCO}_{3}^{-}$exchange ( $\gamma$ cell). Valinomycin-high $\mathrm{K}^{+}$voltage clamping had no effect on the $\mathrm{pH}_{\mathbf{i}}$ response of intercalated cells with bilateral $\mathrm{Cl}^{-}-\mathrm{HCO}_{3}^{-}$exchange. Although the mean rates of $\mathrm{dpH}_{\mathrm{i}} / \mathrm{dt}$ following apical $\mathrm{Cl}^{-}$removal were similar in $\beta$ cells compared to $\gamma$ cells, a wide range of apical rates was seen among individual $\beta$ and $\gamma$ intercalated cells. Neither the apical nor the basolateral $\mathrm{Cl}^{-}-\mathrm{HCO}_{3}^{-}$ exchanger in $\gamma$ cells was inhibited by $0.5 \mathrm{mM} \mathrm{H_{2 } D I D S . ~ B i n d - ~}$ ing of apical peanut lectin was seen both in $\beta$ cells and in $\gamma$ cells. In $41 \%$ of CCDs with four to seven intercalated cells studied, all intercalated cells were of the same subtype. We conclude that the majority of intercalated cells from the rabbit outer $\mathrm{CCD}$ have both apical and basolateral $\mathrm{Na}^{+}$-independent $\mathrm{Cl}^{-}-\mathrm{HCO}_{3}^{-}$ exchangers ( $\gamma$ cells), which are stilbene-insensitive. Intercalated cells with only basolateral $\mathrm{Cl}^{-}-\mathrm{HCO}_{3}^{-}$exchange are very uncommon in the rabbit outer $\mathrm{CCD}$. There is a tendency for all intercalated cells in a given rabbit outer CCD to be of the same subtype (either all $\beta$ cells or all $\gamma$ cells), suggesting the presence of CCD intertubule heterogeneity at the same cortical level. This finding may account for intertubule differences in transepithelial $\mathrm{H}^{+}$-base transport. (J. Clin. Invest. 1994. 93:417-423.) Key words: acid-base $\bullet$ intracellular $\mathrm{pH} \bullet$ intercalated cells • confocal microscopy • anion exchange
\end{abstract}

\section{Introduction}

The cortical collecting duct $(\mathrm{CCD})^{1}$ is a heterogeneous epithelium composed of two main cell types: principal cells and intercalated

Portions of this work were presented at the annual meeting of the American Society of Nephrology, 20-21 November, 1991, Baltimore, MD, and were published in abstract form (1991. J. Am. Soc. Nephrol. 2:699).

Address correspondence to Dr. Cheryl Emmons, Nephrology Division, UCLA Center for the Health Sciences, 10833 Le Conte Boulevard, Factor 7-453, Los Angeles, CA 90024. 1993.

Received for publication 7 April 1993 and in revised form 11 August

1. Abbreviations used in this paper: BCECF-AM, acetoxymethyl ester of 2',7'-bis-(2-carboxyethyl)-5-(and-6)carboxyfluorescein; CCD, cor-

The Journal of Clinical Investigation, Inc.

Volume 93, January 1994, 417-423 cells (1). It is the latter group of cells that is believed to mediate transepithelial CCD acid-base transport. Intercalated cells have been traditionally divided into two types based on their morphology, antibody binding properties, and acid-base transport characteristics. Bicarbonate secretion is attributed to $\beta$ intercalated cells, which have been modeled with an apical $\mathrm{Na}^{+}$-independent $\mathrm{Cl}^{-}$$\mathrm{HCO}_{3}^{-}$-exchanger, a basolateral $\mathrm{H}^{+}$-ATPase, and a basolateral $\mathrm{Cl}^{-}$ channel. $\alpha$ intercalated cells are thought to effect $\mathrm{CCD} \mathrm{HCO}_{3}^{-}$absorption and are modeled with an apical $\mathrm{H}^{+}$-ATPase, a basolateral $\mathrm{Na}^{+}$-independent $\mathrm{Cl}^{-}-\mathrm{HCO}_{3}^{-}$exchanger and a basolateral $\mathrm{Cl}^{-}$ channel (2-8). In addition, apical lectin binding has been considered a characteristic marker for $\beta$ cells $(3,9,13)$. Although $\beta$ cells do not bind antibodies to the erythrocyte anion exchanger band 3 , $\alpha$ cells do exhibit basolateral staining $(9,15,19)$. However, recent morphologic and immunocytochemical studies have identified "hybrid" cells with features attributed to both intercalated cell subtypes $(14-17,29)$. The functional significance of these findings is unknown.

Much of the current understanding of CCD acid-base transport characteristics is derived from whole tubule studies. The heterogeneous nature of the CCD makes it difficult to ascertain function on a single-cell level. Optical approaches have been used to study single-cell $\mathrm{H}^{+}$-base transport; however, the cylindrical geometry of the tubule has made optical studies of individual cells troublesome due to the acquisition of out-of-focus information. This difficulty can be overcome using confocal microscopy (10). The present study was undertaken to functionally characterize the distribution of $\mathrm{Na}^{+}$-independent $\mathrm{Cl}^{-}$$\mathrm{HCO}_{3}^{-}$exchange in single intercalated cells in the rabbit outer CCD using dual excitation laser scanning confocal microscopy. The results indicate that the majority of rabbit outer CCD intercalated cells do not fit either of the two classic intercalated cell models.

\section{Methods}

Tubule perfusion. Male New Zealand White rabbits weighing $4 \mathrm{lbs}$ and with free access to rabbit chow (Prolab; Agway Country Foods, Inc., Syracuse, NY) were killed by cervical dislocation. The left kidney was removed, cut in coronal sections, and placed in chilled solution 1 ( Table I). Cortical collecting ducts were dissected from the outer mm of cortex, with the most superficial end starting at the most distal connecting tubule arcade into the collecting duct (11). The tubule was transferred to a 100- $\mu$ l laminar flow chamber and the peritubular bathing solution was exchanged at a rate of $2 \mathrm{ml} / \mathrm{min}$.

Solutions. The solutions used in the study are listed in Table I. All were $\mathrm{Na}^{+}$-free (tetramethylammonium replacement) to eliminate any contribution of $\mathrm{Na}^{+}$-dependent transport processes to alterations in $\mathrm{pH}_{\mathrm{i}}$. Solution 1 was used for the dissection solution. Solution 2 was the initial perfusing and bathing solution, except where specified. Solution 3 was free of $\mathrm{Cl}^{-}$(gluconate replacement). Solutions 4 and 5 were used

tical collecting duct; 6-CF, 6-carboxylfluorescein; $\mathrm{H}_{2}$ DIDS, 4,4'diisothiocyanatodihydrostilbene-2,2'-disulfonic acid; $\mathrm{pH}_{\mathrm{i}}$, intracellular $\mathrm{pH}$. 
Table I. List of Solutions Used in the Study

\begin{tabular}{|c|c|c|c|c|c|c|}
\hline Solutions & 1 & 2 & 3 & 4 & 5 & 6 \\
\hline Tetramethylammonium hydroxide & 0 & 0 & 115 & 0 & 0 & 0 \\
\hline Tetramethylammonium chloride & 140 & 115 & 0 & 20 & 0 & 0 \\
\hline Gluconic acid lactone & 0 & 0 & 115 & 0 & 20 & 0 \\
\hline Tetramethylammonium bicarbonate & 0 & 25 & 25 & 25 & 25 & 0 \\
\hline $\mathrm{KCl}$ & 0 & 0 & 0 & 95 & 0 & 115 \\
\hline $\mathrm{K}_{2} \mathrm{HPO}_{4}$ & 2.5 & 2.5 & 2.5 & 2.5 & 2.5 & 2.5 \\
\hline K-gluconate & 0 & 0 & 0 & 0 & 95 & 0 \\
\hline $\mathrm{CaCl}_{2}$ & 1 & 1 & 0 & 1 & 0 & 1 \\
\hline Ca-gluconate & 0 & 0 & 3.5 & 0 & 3.5 & 0 \\
\hline $\mathrm{MgCl}_{2}$ & 1 & 1 & 0 & 1 & 0 & 1 \\
\hline Mg-gluconate & 0 & 0 & 1 & 0 & 1 & 0 \\
\hline Hepes acid & 5 & 0 & 0 & 0 & 0 & 5 \\
\hline L-alanine & 5 & 5 & 5 & 5 & 5 & 5 \\
\hline Glucose & 5 & 5 & 5 & 5 & 5 & 5 \\
\hline
\end{tabular}

All concentrations are in $\mathrm{mmol} / \mathrm{liter}$.

for the valinomycin experiments, and solution 6 was used for calibration of $\mathrm{pH}_{\mathrm{i}}$ with $10 \mu \mathrm{M}$ nigericin added. The $\mathrm{HCO}_{3}^{-}$-containing solutions were bubbled with $6.5 \% \mathrm{CO}_{2}$ and $93.5 \% \mathrm{O}_{2}$, while the Hepes-containing solutions were bubbled with $100 \% \mathrm{O}_{2}$. Tetramethylammonium bicarbonate was made by bubbling tetramethylammonium hydroxide with $100 \% \mathrm{CO}_{2}$. Glass tubing, surrounded by heated water jackets, connected the solution reservoirs and the perfusion chamber to prevent any $\mathrm{CO}_{2}$ or temperature loss. The $\mathrm{pH}$ of all solutions was 7.4 , and all experiments were performed at $37^{\circ} \mathrm{C}$.

$\mathrm{pH}_{\mathrm{i}}$ measurements/confocal imaging. To measure $\mathrm{pH}_{\mathrm{i}}, 5 \mu \mathrm{M}$ acetoxymethyl ester of 2',7'-bis (2-carboxyethyl)-5 (and -6) carboxyfluorescein (BCECF-AM) was added to the appropriate perfusate solution for $15 \mathrm{~min}$, resulting in selective dye loading of only the intercalated cells and confirmed by "rough" surface appearance with transmission imaging (12). The perfusate was then changed to the appropriate dyefree solution for $10 \mathrm{~min}$ before any data was recorded. The fluorescent measurements were accomplished with the use of a dual-excitation laser-scanning inverted confocal fluorescent microscope, as previously described (10). The previous methodology was modified as follows. A laser-scanning system (model MRC600; BioRad Laboratories, Richmond, CA) was coupled to the side port of a Diaphot inverted microscope (Nikon Inc., Melville, NY). An argon laser (model 5424A; Ion Laser Technology, Inc., Salt Lake City, UT) was used for the 488-nm excitation and a helium-cadmium laser (model 4214NB; Liconix, Santa Clara, CA) provided the 442-nm excitation. A $40 \times$ fluorite objective (N.A. 0.8; Nikon Inc.) was used in all experiments. $\mathrm{pH}_{\mathrm{i}}$ was measured from an area of cytoplasm of $\sim 3$ to $5 \mu \mathrm{m}$ in diameter in up to 7 intercalated cells along a $250-\mu \mathrm{m}$ length of tubule (UMANS software; BioRad Laboratories). A zoom factor of 2.5 was used to obtain images of the tubule (final magnification of 800). A computer-driven electronic shutter (Vincent Associates, Rochester, NY) in front of each laser limited the duration of laser exposure to $1 \mathrm{~s}$ per ratio. Excitation ratio measurements were taken every $5 \mathrm{~s}$ after a solution change and the rate of change of $\mathrm{pH}_{\mathrm{i}}\left(\mathrm{dpH}_{\mathrm{i}} / \mathrm{d} t\right)$ was evaluated in the initial $20 \mathrm{~s}$.

Materials. 4,4'diisothiocyanatodihydrostilbene-2,2'-disulfonic acid $\left(\mathrm{H}_{2} \mathrm{DIDS}\right)$ and BCECF-AM were from Molecular Probes, Inc. (Eugene, $\mathrm{OR}$ ). Tetramethylammonium hydroxide was from Fisher Scientific (Fair Lawn, NJ) and all other chemicals were from Sigma Chemical Co. (St. Louis, MO).

Statistics. All results are reported as mean \pm SEM. Student's unpaired $t$ test was used to compare results from two group means obtained from separate tubules. Student's paired $t$ test was used to compare results of inhibitor studies in the same tubule. Statistical significance was accepted at the $P \leq 0.05$ level.

\section{Results}

Patterns of $\mathrm{Na}^{+}$-independent $\mathrm{Cl}^{-}-\mathrm{HCO}_{3}^{-}$exchange in $\mathrm{CCD}$ intercalated cells. In the initial experiments, $\mathrm{Cl}^{-}$was replaced with gluconate (solution 3 ) sequentially on both sides of the tubule. This protocol was examined in 309 intercalated cells from $72 \mathrm{CCDs}$. Three patterns of $\mathrm{pH}_{\mathrm{i}}$ response were seen (Figs. 1-3). One pattern is illustrated in Fig. 1. In this particular cell, the initial $\mathrm{pH}_{\mathrm{i}}$ was 6.92. Removal of $\mathrm{Cl}^{-}$from the lumen resulted in an increase in $\mathrm{pH}_{\mathrm{i}}$ to a steady-state value of 7.05. $\mathrm{pH}_{\mathrm{i}}$ was not altered further with removal of $\mathrm{Cl}^{-}$from the bath. This pattern of $\mathrm{Cl}^{-}$-base exchange was seen in $39 \%$ of the intercalated cells studied with this protocol and is consistent with the existing model of the $\beta$ intercalated cell, an intercalated cell with only apical anion exchange. In these intercalated cells with only apical $\mathrm{Cl}^{-}$-base exchange, mean baseline $\mathrm{pH}_{\mathrm{i}}$ was $6.94 \pm 0.06$, mean $\mathrm{dpH} \mathrm{H}_{\mathrm{i}} / \mathrm{d} t$ after apical $\mathrm{Cl}^{-}$removal was $1.16 \pm 0.17 \mathrm{pH} / \mathrm{min}$, and mean $\Delta \mathrm{pH}_{\mathrm{i}}$ was $0.33 \pm 0.04 \mathrm{pH}$ units.

A second pattern of $\mathrm{pH}_{\mathrm{i}}$ response is seen in Fig. 2. $\mathrm{pH}_{\mathrm{i}}$ was

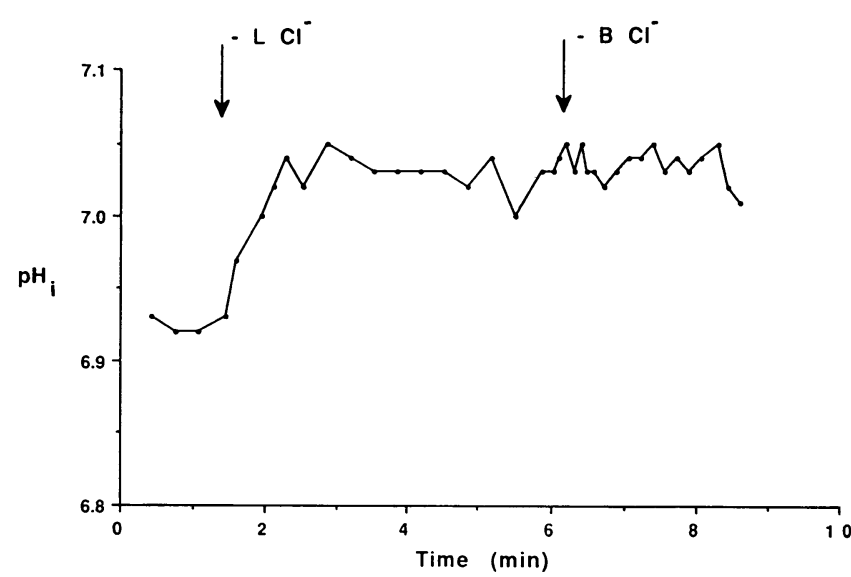

Figure 1. $\mathrm{pH}_{\mathrm{i}}$ response to sequential lumen and basolateral $\mathrm{Cl}^{-}$removal (pattern 1). Removal of lumen $\mathrm{Cl}^{-}$results in intracellular alkalinization, with no futher change in $\mathrm{pH}_{\mathrm{i}}$ from removal of bath $\mathrm{Cl}^{-}$. These results are compatible with the classic $\beta$ cell model. 


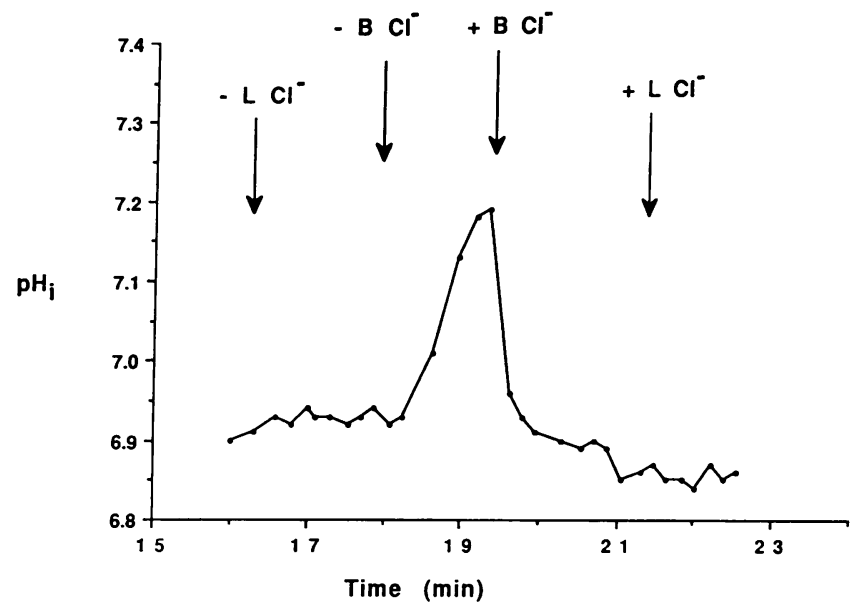

Figure 2. $\mathrm{pH}_{\mathrm{i}}$ response to sequential lumen and basolateral $\mathrm{Cl}^{-}$removal (pattern 2). $\mathrm{pH}_{\mathrm{i}}$ was unchanged after removal of lumen $\mathrm{Cl}^{-}$ and increased in response to removal of bath $\mathrm{Cl}^{-}$. This result was rarely seen and is compatible with the classic $\alpha$ cell model.

not altered with removal of lumen $\mathrm{Cl}^{-}$. However, removal of bath $\mathrm{Cl}^{-}$resulted in an increase in $\mathrm{pH}_{\mathrm{i}}$ from 6.92 to 7.20. This pattern of $\mathrm{Cl}^{-}$-base exchange is consistent with the current model of the $\alpha$ intercalated cell, one with only basolateral anion exchange. This pattern of $\mathrm{Cl}^{-}$-base exchange was seen in only $4 \%$ of CCD intercalated cells, and occurred so infrequently that this cell type could not be studied in any detail.

A third pattern of $\mathrm{pH}_{\mathrm{i}}$ response is seen in Fig. 3. In this cell, baseline $\mathrm{pH}_{\mathrm{i}}$ was 7.02. Removal of lumen $\mathrm{Cl}^{-}$caused alkalinization with subsequent stabilization of $\mathrm{pH}_{\mathrm{i}}$ at 7.21 . In contrast to Fig. 1, removal of basolateral $\mathrm{Cl}^{-}$in this cell caused further alkalinization to $\mathrm{pH}_{\mathrm{i}} 7.30$, with a decrease in $\mathrm{pH}_{\mathrm{i}}$ when $\mathrm{Cl}^{-}$was readded to the bath. This tracing is not consistent with either the current $\alpha$ or $\beta$ intercalated cell models. In a separate study (Fig. 4), bath $\mathrm{Cl}^{-}$was removed initially, resulting in an increase in $\mathrm{pH}_{\mathrm{i}}$ to 7.20 . Readdition of bath $\mathrm{Cl}^{-}$caused the $\mathrm{pH}_{\mathrm{i}}$ to return to its baseline, 7.05. After removal of lumen $\mathrm{Cl}^{-}, \mathrm{pH}_{\mathrm{i}}$

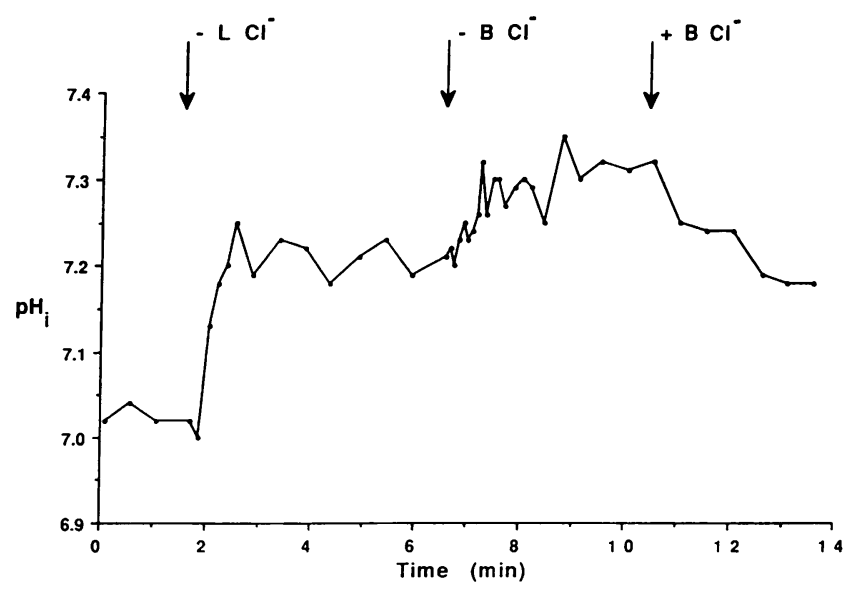

Figure 3. $\mathrm{pH}_{\mathrm{i}}$ response to sequential lumen and basolateral $\mathrm{Cl}^{-}$removal (pattern 3). After removal of lumen $\mathrm{Cl}^{-}, \mathrm{pH}_{\mathrm{i}}$ increased followed by a further cell alkalinization in response to removal of bath $\mathrm{Cl}^{-}$. These findings indicate the presence of bilateral $\mathrm{Cl}^{-}$-base exchange. This new intercalated cell subtype is designated as the $\gamma$ cell.

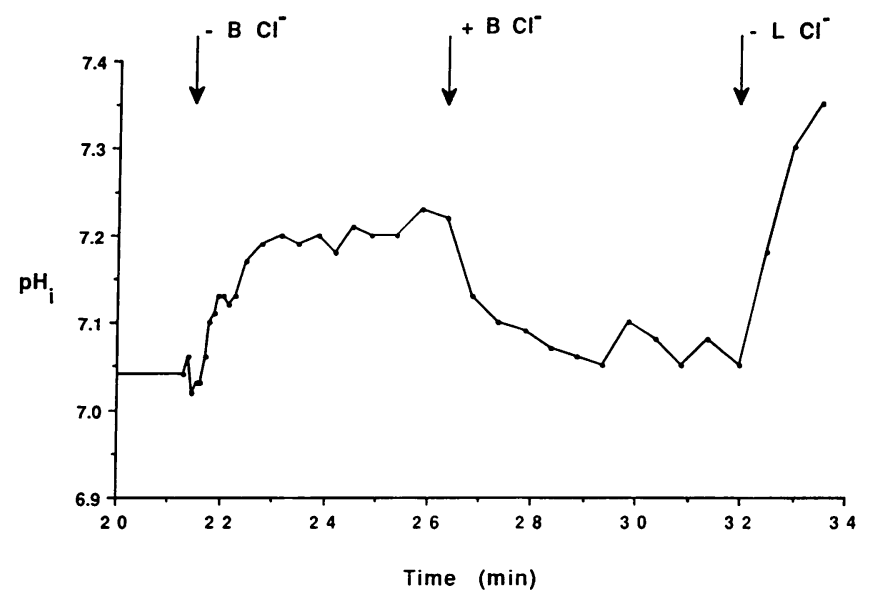

Figure 4. $\mathrm{pH}_{\mathrm{i}}$ response to sequential lumen and basolateral $\mathrm{Cl}^{-}$removal (pattern 3). Removal of bath $\mathrm{Cl}^{-}$caused $\mathrm{pH}_{\mathrm{i}}$ to increase. Readdition of bath $\mathrm{Cl}^{-}$resulted in recovery of $\mathrm{pH}_{\mathrm{i}}$. Removal of lumen $\mathrm{Cl}^{-}$resulted in an increase in $\mathrm{pH}_{\mathrm{i}}$.

increased to 7.35. The sequence of $\mathrm{Cl}^{-}$removal made no difference in the $\mathrm{pH}_{\mathrm{i}}$ response seen. $57 \%$ of the intercalated cells studied demonstrated this pattern of an increase in $\mathrm{pH}_{\mathrm{i}}$ after both bath and lumen $\mathrm{Cl}^{-}$removal. These results are best explained by an intercalated cell with bilateral $\mathrm{Cl}^{-}$-base exchangers $(\gamma$ cell $)$. In these intercalated cells with bilateral $\mathrm{Cl}^{-}$base exchangers, baseline $\mathrm{pH}_{\mathrm{i}}$ was $7.06 \pm 0.06$. The $\mathrm{dpH}_{\mathrm{i}} / \mathrm{d} t$ after apical $\mathrm{Cl}^{-}$removal was $1.25 \pm 0.18$ with a $\Delta \mathrm{pH}_{\mathrm{i}}$ of $0.30 \pm 0.04$. The $\mathrm{dpH}_{\mathrm{i}} / \mathrm{d} t$ after basolateral $\mathrm{Cl}^{-}$removal was $0.86 \pm 0.15$ with a $\Delta \mathrm{pH}_{\mathrm{i}}$ of $0.29 \pm 0.05$ (all NS vs. intercalated cells with only apical anion exchange).

Further experiments were done in separate tubules to eliminate the possibility of any conductive pathway as a cause for the apical and basolateral $\mathrm{Cl}^{-}$-induced $\mathrm{pH}_{\mathrm{i}}$ changes. The protocol was repeated in the presence of $5 \mu \mathrm{M}$ luminal and basolateral high $\mathrm{K}^{+}$-valinomycin solutions (solution 4 , Table I) to clamp the apical and basolateral membrane potential. The results of such an experiment are seen in Fig. 5. In this cell, removal of lumen $\mathrm{Cl}^{-}$(solution 5) resulted in intracellular alkalinization, as expected in a cell with apical anion exchange. Removal of bath $\mathrm{Cl}^{-}$resulted in further alkalinization, which was reversible with readdition of $\mathrm{Cl}^{-}$to the bath. The $\mathrm{dpH}_{\mathrm{i}} / \mathrm{d} t$ after apical $\mathrm{Cl}^{-}$removal in the presence of high $\mathrm{K}^{+}$-valinomycin solutions in 32 intercalated cells with bilateral $\mathrm{Cl}^{-}$-base exchange from 12 tubules was $0.92 \pm 0.15$ with a $\Delta \mathrm{pH}_{\mathrm{i}}$ of $0.25 \pm 0.05$. The $\mathrm{dpH}_{\mathrm{i}} / \mathrm{d} t$ after basolateral $\mathrm{Cl}^{-}$removal was $1.13 \pm 0.16$ with a $\Delta \mathrm{pH}_{\mathrm{i}}$ of $0.24 \pm 0.04$.

Although the mean rates of $\mathrm{dpH}_{\mathrm{i}} / \mathrm{d} t$ in response to luminal $\mathrm{Cl}^{-}$removal are similar for both $\beta$ and $\gamma$ intercalated cell subtypes, an array of rates was seen, as depicted in Fig. 6 . These data suggest that within a given intercalated cell subtype ( $\beta$ cells with only apical $\mathrm{Cl}^{-}$-base exchange and $\gamma$ cells with bilateral $\mathrm{Cl}^{-}$-base exchange), there is a wide range of $\mathrm{Cl}^{-}$-base transport rates.

Effect of $\mathrm{H}_{2} \mathrm{DIDS}$ on $\mathrm{Cl}^{-}$-base exchange in $\mathrm{CCD}$ intercalated cells with bilateral $\mathrm{Cl}^{-}$-base exchange. To further characterize the CCD intercalated cells with bilateral $\mathrm{Cl}^{-}$-base exchange, the effect of the stilbene inhibitor $\mathrm{H}_{2}$ DIDS on these transporters was studied in separate experiment. In this protocol, a given intercalated cell was first subtyped functionally by 


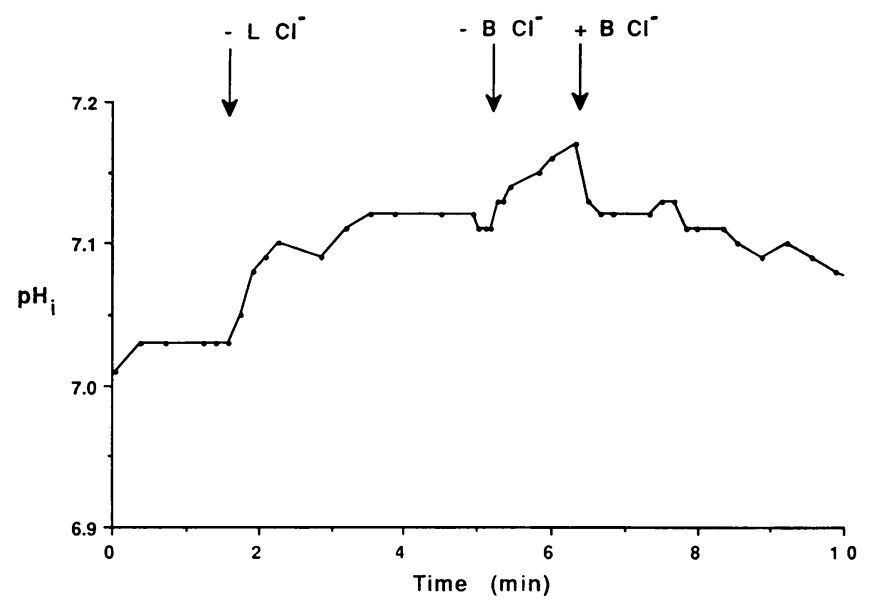

Figure 5. $\mathrm{pH}_{\mathrm{i}}$ response to sequential lumen and basolateral $\mathrm{Cl}^{-}$removal in the presence of $5 \mu \mathrm{M}$ valinomycin (lumen and bath). The $\mathrm{pH}_{\mathrm{i}}$ response to luminal and basolateral $\mathrm{Cl}^{-}$removal did not differ from control cells, suggesting that apical and basolateral $\mathrm{Cl}^{-}$-base exchangers, rather than parallel $\mathrm{Cl}^{-}$and $\mathrm{H}^{+}$-base conductive pathways, account for the results.

$\mathrm{Cl}^{-}$removal on both sides of the tubule. Then, $0.5 \mathrm{mM}$ $\mathrm{H}_{2}$ DIDS was added to either the lumen or bath for $20 \mathrm{~min}$ and the $\mathrm{Cl}^{-}$removal studies were repeated in the presence of the stilbene inhibitor. Fig. 7 shows the lack of effect of luminal 0.5 $\mathrm{mM} \mathrm{H} \mathrm{H}_{2}$ DIDS on the apical anion exchanger in a representative intercalated cell with bilateral $\mathrm{Cl}^{-}$-base exchange. Baseline $\mathrm{pH}_{\mathrm{i}}$ was 6.79. Removal of lumen $\mathrm{Cl}^{-}$caused alkalinization to $\mathrm{pH}_{\mathrm{i}}$ 6.95. $\mathrm{Cl}^{-}$was returned to the lumen and $0.5 \mathrm{mM} \mathrm{H}_{2}$ DIDS was added for $20 \mathrm{~min}$. Then, luminal $\mathrm{Cl}^{-}$was again removed, with a similar degree of alkalinization resulting. The additional alkalinization in response to removal of bath $\mathrm{Cl}^{-}$indicates that this intercalated cell was one with bilateral $\mathrm{Cl}^{-}$-base exchange. Simi-

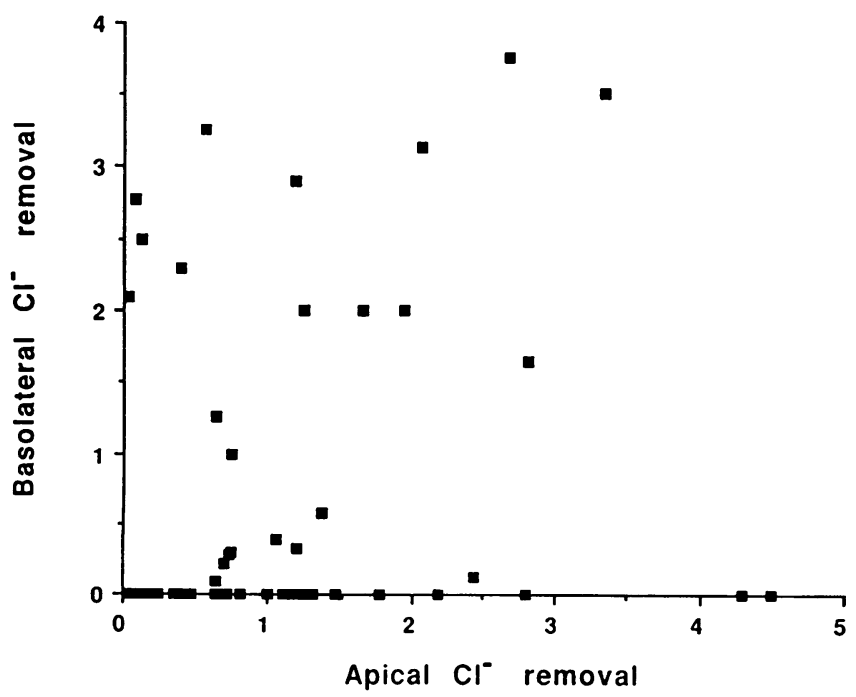

Figure 6. $\mathrm{dpH}_{\mathrm{i}} / \mathrm{d} t$ in response to luminal $\mathrm{Cl}^{-}$removal ( $x$ axis) vs. that observed with subsequent basolateral $\mathrm{Cl}^{-}$removal ( $y$ axis) in individual intercalated cells. Rather than a clustering of values into two clearly separated groups, a wide range of results is evident. Note the paucity of $\alpha$ cells with only basolateral $\mathrm{Cl}^{-}$-base exchange.

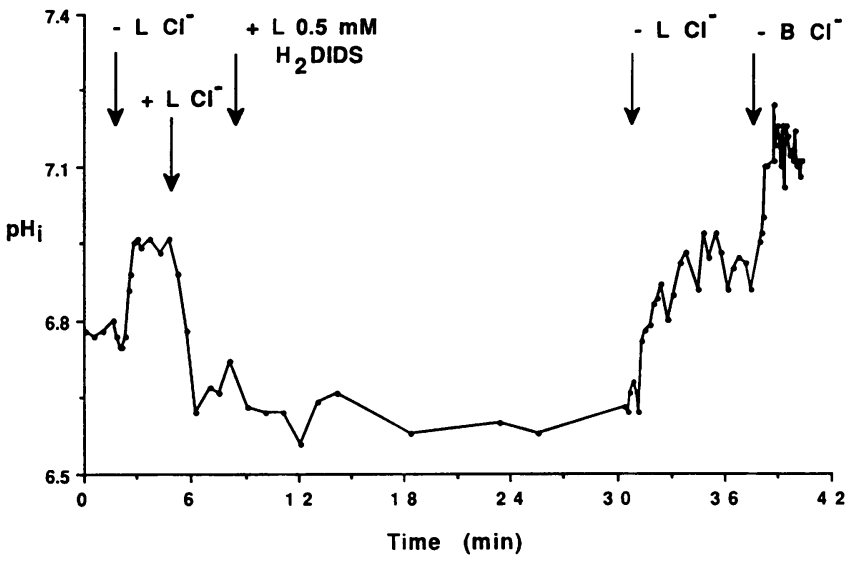

Figure 7. $\mathrm{pH}_{\mathrm{i}}$ response of a $\gamma$ intercalated cell in response to luminal $\mathrm{Cl}^{-}$removal before and after the addition of $0.5 \mathrm{mM}$ luminal $\mathrm{H}_{2}$ DIDS. There was no effect on the intracellular alkalinization resulting from removal of lumen $\mathrm{Cl}^{-}$after 20 -min exposure to $0.5 \mathrm{mM}$ luminal $\mathrm{H}_{2}$ DIDS.

lar studies in 40 intercalated cells ( 11 tubules) with bilateral $\mathrm{Cl}^{-}$-base exchange revealed no difference in either the rates of alkalinization in response to removal of lumen $\mathrm{Cl}^{-}$after stilbene exposure or the resultant $\Delta \mathrm{pH}_{\mathrm{i}}$ values $\left(\mathrm{dpH}_{\mathrm{i}} / \mathrm{d} t\right.$ $1.11 \pm 0.08$ vs. $0.96 \pm 0.10, \Delta \mathrm{pH}_{\mathrm{i}} 0.35 \pm 0.02$ vs. $0.31 \pm 0.04$, paired, NS). These results demonstrate that the apical anion exchanger in CCD intercalated cells with bilateral anion exchange is not $\mathrm{H}_{2}$ DIDS-sensitive.

Fig. 8 shows the lack of effect of basolateral $\mathrm{H}_{2}$ DIDS on the basolateral $\mathrm{Cl}^{-}$-base exchanger in an intercalated cell with bilateral $\mathrm{Cl}^{-}$-base exchange. Removal of lumen $\mathrm{Cl}^{-}$caused $\mathrm{pHi}$ to increase, followed by a further cell alkalinization after removal of basolateral $\mathrm{Cl}^{-}$. After $20 \mathrm{~min}$ of $\mathrm{H}_{2}$ DIDS exposure on the basolateral side, sequential $\mathrm{Cl}^{-}$removal was repeated, with no effect on the resulting degree of alkalinization. Similar studies in nine intercalated cells with bilateral $\mathrm{Cl}^{-}$-base exchange from seven tubules revealed no difference in either the rates of alkalinization in response to removal of basolateral $\mathrm{Cl}^{-}$after stil-

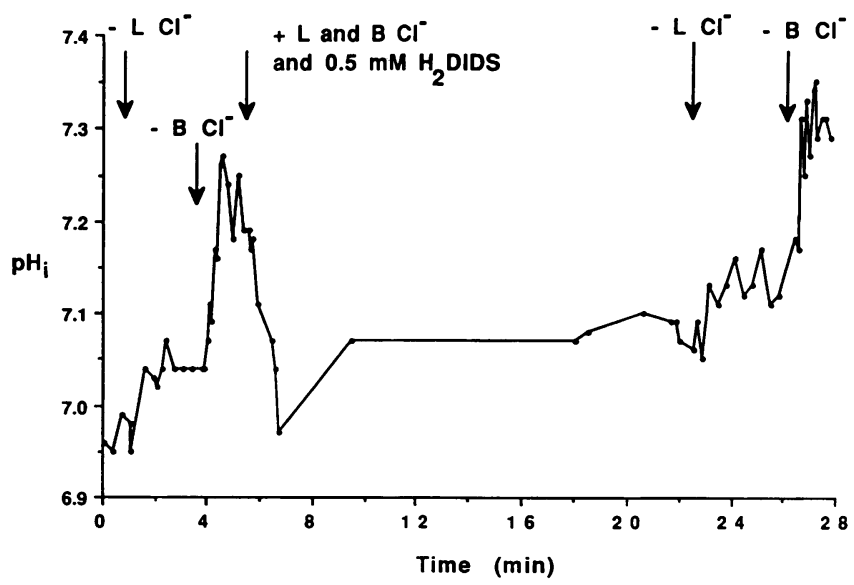

Figure 8. $\mathrm{pH}_{\mathrm{i}}$ response of a $\gamma$ intercalated cell in response to basolateral $\mathrm{Cl}^{-}$removal before and after $0.5 \mathrm{mM}$ basolateral $\mathrm{H}_{2}$ DIDS. The intracellular alkalinization due to removal of bath $\mathrm{Cl}^{-}$was unchanged after 20-min exposure to $0.5 \mathrm{mM}$ basolateral $\mathrm{H}_{2}$ DIDS. 
bene exposure or the resultant $\Delta \mathrm{pH}_{\mathrm{i}}$ values $\left(\mathrm{dpH}_{\mathrm{i}} / \mathrm{d} t\right.$ $0.75 \pm 0.19$ vs. $0.95 \pm 0.30, \Delta \mathrm{pH}_{\mathrm{i}} 0.12 \pm 0.02$ vs. $0.15 \pm 0.03$, paired, NS). These results demonstrate that the basolateral anion exchanger in CCD intercalated cells with bilateral anion exchange is not $\mathrm{H}_{2}$ DIDS-sensitive.

Lectin binding in CCD intercalated cells. Binding of peanut lectin to the apical membrane has been used as a marker for the classic $\beta$ intercalated cell model $(3,9,13)$. In eleven separate tubules, experiments were done to determine whether intercalated cells with bilateral $\mathrm{Cl}^{-}$-base exchange bind peanut lectin. The tubules were initially perfused with $50 \mu \mathrm{g} / \mathrm{ml}$ FITCpeanut lectin and cells exhibiting apical peanut lectin binding were identified as seen in Fig. 9. Then, the perfusate was changed to one containing BCECF-AM. After dye loading, $\mathrm{Cl}^{-}$ was removed sequentially from the apical and basolateral sides of the tubule, as described previously. Of $44 \mathrm{CCD}$ intercalated cells that bound apical peanut lectin, $48 \%$ had only apical anion exchange and $52 \%$ had both apical and basolateral anion exchange. Thus, $\mathrm{CCD}$ intercalated cells with bilateral $\mathrm{Cl}^{-}$-base exchange do bind lectin. Therefore, apical peanut lectin binding is not a specific marker for intercalated cells with exclusively apical $\mathrm{Cl}^{-}$-base exchange ( $\beta$ cells).

Pattern of $\mathrm{Cl}^{-}$-base exchange among $\mathrm{CCDs}$. The ability to study several intercalated cells simultaneously in the same tubule permitted comparison of intercalated cell $\mathrm{Cl}^{-}$-base exchange patterns within a given tubule along a $250-\mu \mathrm{m}$ length. Of 49 tubules in which 4 to 7 intercalated cells were studied, $41 \%$ of these tubules had intercalated cells with only one pattern of anion exchange. Fig. 10 illustrates the distribution of anion exchange in intercalated cells of individual tubules with either four, five, six, or seven intercalated cells studied in each tubule. Of those tubules with only one pattern of intercalated cell anion exchange, $35 \%$ of the tubules had exclusively intercalated cells with apical anion exchange ( $\beta$ cells) and $65 \%$ of the tubules had exclusively intercalated cells with both apical and

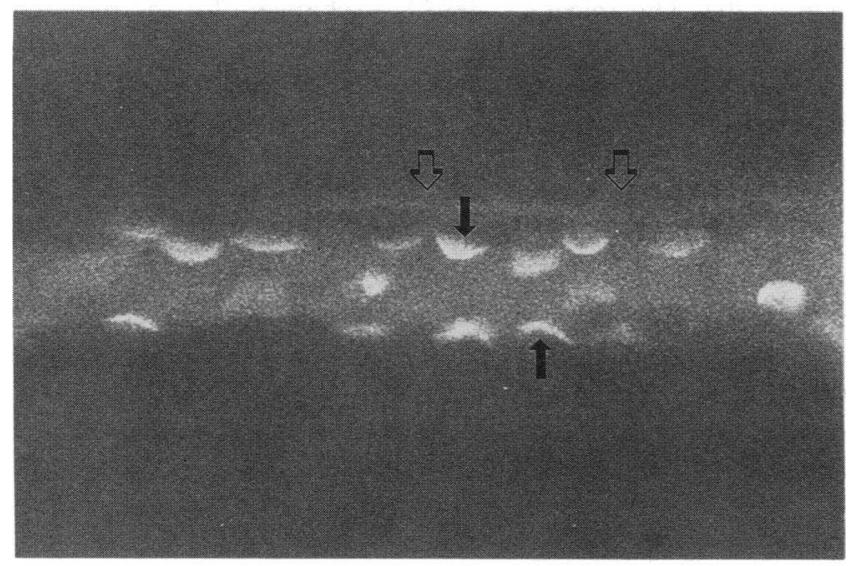

Figure 9. Fluorescent image of a cortical collecting duct after luminal perfusion with $50 \mu \mathrm{g} / \mathrm{ml}$ FITC-peanut lectin. After identification of intercalated cells that bound lectin to their apical membrane, the tubule was luminally loaded with $\mathrm{BCECF}-\mathrm{AM}$, and $\mathrm{Cl}^{-}$-base exchange was assessed on both sides of the tubule. In this tubule, cells between the open arrows were studied. Cells designated by a dark arrow exhibited both apical and basolateral $\mathrm{Cl}^{-} \cdot \mathrm{HCO}_{3}^{-}$exchange ( $\gamma$ cells), while the remaining cells had only apical $\mathrm{Cl}^{-}-\mathrm{HCO}_{3}^{-}$exchange ( $\beta$ cells).

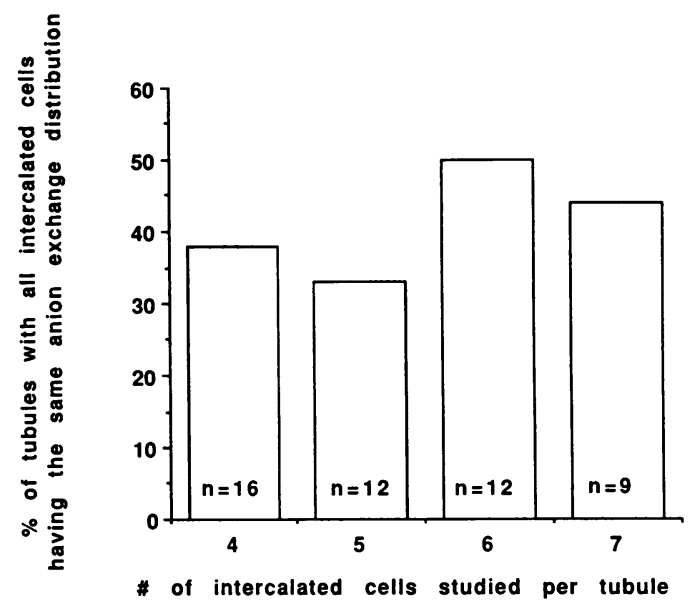

Figure 10. Percentage of tubules with four to seven intercalated cells demonstrating the same anion exchange distribution. The $x$ axis indicates the number of cells studied in a $250-\mu \mathrm{M}$ length of an individual tubule. The number within the bars indicates the number of tubules studied. The same distribution of intercalated cell anion exchange was seen in $38 \%$ of the 16 CCDs with 4 intercalated cells studied per tubule, $33 \%$ of the 12 CCDs with 5 intercalated cells studied per tubule, $50 \%$ of the 12 CCDs with 6 intercalated cells studied per tubule, and $44 \%$ of the 9 CCDs with 7 intercalated cells studied per tubule. Taken together, an average of $41 \%$ of all these CCDs ( 49 tubules) had the same distribution of intercalated cell anion exchange.

basolateral anion exchange ( $\gamma$ cells). The finding that there are CCDs with one intercalated cell type may account for transepithelial $\mathrm{H}^{+}$-base and $\mathrm{Cl}^{-}$transport differences that exist among CCDs dissected from the same level in the outer cortex.

\section{Discussion}

Intercalated cells in the CCD are presently divided into two subtypes: $\alpha$ and $\beta$ cells. The purpose of the present study was to functionally characterize the distribution of $\mathrm{Cl}^{-}$-base exchange activity in single rabbit intercalated cells in the outer CCD. $\mathrm{Cl}^{-}$-base exchange activity was documented by the $\mathrm{pH}_{\mathrm{i}}$ responses to sequential removal of apical and basolateral $\mathrm{Cl}^{-}$in the same cell. The approach allowed a functional determination of whether the traditional subdivision of intercalated cell subtypes into two categories has been overly simplistic. The results demonstrate that the majority of intercalated cells from the rabbit outer $\mathrm{CCD}$ have both apical and basolateral $\mathrm{Na}^{+}$-independent $\mathrm{Cl}^{-}$-base exchangers that are stilbene-insensitive. In keeping with the nomenclature given initially to the carbonic anhydrase-rich cells of the turtle bladder, and then extended to CCD intercalated cells on the basis of morphologic similarities, $(3,24,27)$ we propose that the newly identified CCD intercalated cells with bilateral $\mathrm{Na}^{+}$-independent $\mathrm{Cl}^{-}-\mathrm{HCO}_{3}^{-}$exchangers be called $\gamma$ cells. Whether these cells also exist in the turtle bladder is unknown. In addition, intercalated cells with only basolateral $\mathrm{Cl}^{-}$-base exchange ( $\alpha$ cells) are very uncommon in the rabbit outer CCD. Intercalated cells with exclusively apical $\mathrm{Cl}^{-}$-base exchange ( $\beta$ cells) and cells with bilateral $\mathrm{Cl}^{-}$-base exchange ( $\gamma$ cells) were both found to bind peanut lectin on the apical membrane. Surprisingly, a large percentage of CCDs had intercalated cells of only one subtype. 
One scientific concern must be addressed regarding the use of $\mathrm{Na}^{+}$-free solutions in this study. It is possible that the magnitude of anion exchange could be decreased due to the lower $\mathrm{pH}_{\mathrm{i}}$ in the presence of zero $\mathrm{Na}^{+}$solutions. $\mathrm{A} \mathrm{Na}^{+}$-free protocol was chosen because the purpose of this study was to examine $\mathrm{Na}^{+}$-independent $\mathrm{Cl}^{-}$-base exchange. In the presence of $\mathrm{Na}^{+}$, other $\mathrm{Na}^{+}$-dependent transport processes could minimize $\mathrm{pH}_{\mathrm{i}}$ changes. It is unlikely that either apical or basolateral $\mathrm{Cl}^{-}$-base exchange was significantly underestimated in this study for the following reasons. $96 \%$ of the 309 intercalated cells studied demonstrated apical anion exchange. Therefore, in only $4 \%$ of the 309 intercalated cells would apical anion exchange have been missed. If basolateral anion exchange was missed, the percentage of $\gamma$ cells would be even greater than $57 \%$. However, it is unlikely that basolateral anion exchange was underestimated due to a low $\mathrm{pH}_{\mathrm{i}}$ effect since, after luminal $\mathrm{Cl}^{-}$removal, the starting $\mathrm{pH}_{\mathrm{i}}$ increased to $\sim 7.20$ before basolateral $\mathrm{Cl}^{-}$removal. Taken together, it is unlikely that in $\mathrm{Na}^{+}$-containing solutions, the percentages of intercalated cell subtypes would have varied significantly from the results reported in this study.

Although, intercalated cells have been traditionally divided into two distinct subgroups, several recent studies have identified intercalated cells that do not fit into the conventional categories of $\alpha$ and $\beta$. Based on cellular morphology from transmission electron microscopy, Ridderstrale and colleagues were unable to divide rabbit CCD intercalated cells into two distinct groups, but noted several ultrastructural manifestations that had "subtle and gradual differences, with many intermediate variations" (14). Using antibodies against band 3 and $\mathrm{H}^{+}$ATPase, Alper et al. found that $1 \%$ of rat intercalated cells had apical $\mathrm{H}^{+}$ATPase staining with no band 3 labeling (15). Schwartz et al. characterized intercalated cells in perfused rabbit CCDs with 6-carboxyfluorescein (6-CF) uptake, peanut lectin binding, and luminal endocytosis, and found 5 categories of cells: $6-\mathrm{CF}$ positive only, $6-\mathrm{CF}$ and lectin positive (consistent with the $\beta$ cell model), 6-CF and endocytosis positive (consistent with the $\alpha$ cell model ), lectin positive only, and endocytosis positive only (29). A similar study by Schuster and coworkers combined lectin binding and antibodies against $\mathrm{H}^{+}$ATPase and band 3 to identify subtypes of rabbit intercalated cells and found that $75 \%$ of intercalated cells had diffuse $\mathrm{H}^{+}$ATPase staining with either weak or bright apical lectin caps, consistent with the classical $\beta$ cell model. However, $13 \%$ had apical $\mathrm{H}^{+}$ATPase with bright apical lectin caps, $5 \%$ had diffuse $\mathrm{H}^{+}$ATPase with no lectin binding, and $4 \%$ had bright lectin staining with no $\mathrm{H}^{+}$ATPase. Only $2 \%$ of cells had staining characteristics compatible with the current $\alpha$ cell model, apical $\mathrm{H}^{+}$ATPase staining with no lectin binding (16). More recently, Bastani et al. identified six patterns of $\mathrm{H}^{+}$ATPase immunocytochemistry in rat CCD intercalated cells: well-polarized apical staining, poorly polarized apical staining, diffuse, apical and basolateral, poorly polarized basolateral staining, and well polarized basolateral staining (17). The present results provide the first functional evidence for an intercalated cell that does not fit the classic $\alpha$ or $\beta$ cell models. That the number of $\mathrm{CCD}$ intercalated cells with bilateral $\mathrm{Cl}^{-}$-base exchange ( $\gamma$ cells) identified by $\mathrm{pH}_{\mathrm{i}}$ measurements is greater than the number of "hybrid" cells found in the immunocytochemical studies may result from the lack of a suitable immunocytochemical marker for the apical $\mathrm{Cl}^{-}$-base exchanger.

The direction in which $\mathrm{HCO}_{3}^{-}$is transported by the CCD is known to be a function of the in vivo acid-base status of the animal (18). Based on the traditional intercalated cell models, the $\mathrm{Cl}^{-}$-base exchanger and $\mathrm{H}^{+} \mathrm{ATPase}$ in $\alpha$ and $\beta$ intercalated cells are present on opposite cell membranes. Some authors have proposed that $\alpha$ and $\beta$ cells can reverse their polarity and interconvert, causing a change in the direction of $\mathrm{HCO}_{3}^{-}$transport (3). Remodeling of the apical membrane with endocytotic removal of the apical $\mathrm{Cl}^{-}-\mathrm{HCO}_{3}^{-}$exchanger of $\beta$ cells has been demonstrated in response to an in vitro acid incubation, although development of new basolateral transport systems was not investigated in this study (19). Thus, reversal of functional polarity of intercalated cells was not demonstrated.

There is evidence that suggests that $\alpha$ and $\beta$ intercalated cells are distinct cell types which do not interconvert. The apical membrane of either rabbit or rat intercalated cells is not labeled with band 3 antibodies, while the basolateral membrane of some intercalated cells does label with antibodies to band $3(9) . \mathrm{HCO}_{3}^{-}$reabsorption in rabbit CCDs (presumably an $\alpha$ cell function ) is blocked by basolateral stilbene inhibitors, but apical stilbenes do not inhibit $\mathrm{HCO}_{3}^{-}$secretion (attributed to $\beta$ cells) as reported by Schuster (20). Differences have also been noted in carbonic anhydrase II staining between type A and type B rat CCD intercalated cells (22). Recently, Satlin and Schwartz found a decrease in net $\mathrm{CCD} \mathrm{HCO}_{3}^{-}$secretion in response to an in vitro acid incubation, but no change in $\mathrm{HCO}_{3}^{-}$absorption, suggesting that reversal of functional polarity did not occur between $\alpha$ and $\beta$ cells (23). The identification of $\gamma$ intercalated cells in the present study makes the issue of reversal of polarity and / or remodeling of $\alpha$ and $\beta$ intercalated cells even more complex.

That the rate of apical vs. basolateral $\mathrm{Cl}^{-}$-base exchange varies widely among $\gamma$ cells under control conditions (see Fig. 6 ) suggests the possibility that these cells, as a population, may not have a uniform contribution to transepithelial $\mathrm{H}^{+}$-base transport. The cell currently felt to be responsible for CCD $\mathrm{HCO}_{3}^{-}$secretion, the $\beta$ cell, shares several characteristics with the $\gamma$ cell. $\mathrm{CCD} \mathrm{HCO}_{3}^{-}$secretion is unaffected by luminal stilbenes (20). The apical $\mathrm{Cl}^{-}-\mathrm{HCO}_{3}^{-}$exchanger of $\beta$ and $\gamma$ intercalated cells is not inhibited by stilbenes. In addition, the apical membrane of both cell types binds peanut lectin. These similarities suggest the possibility that both cells may contribute to $\mathrm{CCD} \mathrm{HCO}_{3}^{-}$secretion. A $\gamma$ cell could mediate $\mathrm{HCO}_{3}^{-}$secretion if its apical $\mathrm{Cl}^{-}-\mathrm{HCO}_{3}^{-}$exchanger functioned at a greater rate than its basolateral $\mathrm{Cl}^{-}-\mathrm{HCO}_{3}^{-}$exchanger and if other transport processes (i.e., $\mathrm{H}^{+}$ATPase) mediated efflux of acid-equivalents across the basolateral membrane.

Immunocytochemical studies suggest that $\sim 30 \%$ of rabbit CCD intercalated cells are of the $\alpha$ subtype (9). Using luminal endocytosis as an $\alpha$ cell probe, Schwartz et al. found that $21 \%$ of intercalated cells in the rabbit mid CCD were $\alpha$ cells (20). However, the present studies suggest that cells with only basolateral $\mathrm{Cl}^{-}$-base exchange, consistent with the traditional $\alpha$ cell model, are much less common in the rabbit outer CCD. This is in keeping with the findings of Weiner and Hamm, although the anatomical location of the CCDs examined was not specified (21). As such, the cell responsible for $\mathrm{HCO}_{3}^{-}$absorption in the rabbit $\mathrm{CCD}$ is not known at present. A $\gamma$ cell could mediate $\mathrm{HCO}_{3}^{-}$absorption if the basolateral $\mathrm{Cl}^{-}$-base rate exceeded the apical rate, and if an apical transport pathway for efflux of acid-equivalents is also present. In the proximal tubule, both the apical and basolateral membranes have $\mathrm{Na}^{+}$-independent 
$\mathrm{Cl}^{-}$-base exchangers. Net $\mathrm{HCO}_{3}^{-}$absorption is mediated by other apical $\mathrm{H}^{+}$efflux and basolateral base efflux pathways (28). Whether similar transport processes are present on the $\gamma$ cell is yet to be determined. Against the notion that $\gamma$ cells mediate $\mathrm{HCO}_{3}^{-}$absorption is the finding that the basolateral exchanger of these cells is unaffected by stilbenes. $\mathrm{CCD} \mathrm{HCO}_{3}^{-}$ absorption, however, is stilbene sensitive. Further studies are needed to distinguish the $\mathrm{pH}_{\mathrm{i}}$ regulatory role, the volume regulatory role, and the transepithelial $\mathrm{H}^{+}$-base transport function of the apical and basolateral anion exchangers in $\gamma$ cells.

Previous reports of variability in $\mathrm{CCD} \mathrm{Cl}^{-}$tracer flux have been attributed to axial heterogeneity of intercalated cell subtypes along the rabbit CCD. $\beta$ intercalated cells are thought to provide the major pathway for $\mathrm{CCD}$ transepithelial $\mathrm{Cl}^{-}$transport and are more common in the outer cortex, the region where $\mathrm{Cl}^{-}$tracer flux is greater $(11,24)$. However, another explanation is provided by the finding in the present study that, in many CCDs, the intercalated cells are all of the same subtype. It is feasible that similar $\mathrm{H}^{+}$-base transport properties among intercalated cells in the same tubule account for whole tubule $\mathrm{H}^{+}$-base transport differences. The mechanism(s) of intertubule heterogeneity is not clear. Differences in $\mathrm{CO}_{2}$ tension are not a likely explanation, given the known axial gradient of $\mathrm{CO}_{2}$ in the cortex $(25,26)$. In addition, it is unlikely that local hormonal differences could exist between individual tubules within the cortex. Further studies are required to better understand this phenomenon of interCCD heterogeneity.

In summary, the majority of rabbit outer CCD intercalated cells ( $\gamma$ cells) have both apical and basolateral $\mathrm{Cl}^{-}-\mathrm{HCO}_{3}^{-}$exchangers which are stilbene insensitive. Apical peanut lectin binds to both $\beta$ cells and $\gamma$ cells. In addition, in many rabbit outer CCDs, intercalated cells in a given tubule are of the same subtype, suggesting the presence of intertubule heterogeneity.

\section{Acknowledgments}

This work was supported by a Veterans Affairs Career Development Research Associate Award (to C. Emmons) and by a National Institutes of Health grant (851-IG-4 to I. Kurtz). Dr. Kurtz is an Established Investigator of the American Heart Association.

\section{References}

1. Madsen, K. M., and C. C. Tisher. 1986. Structural-functional relationships along the distal nephron. Am. J. Physiol. 250:F1-F15.

2. Star, R. A., M. B. Burg, and M. A. Knepper. 1985. Bicarbonate secretion and chloride absorption by rabbit cortical collecting duct. Role of chloride/bicarbonate exchange. J. Clin. Invest. 76:1123-1130.

3. Schwartz, G. J., J. Barasch, and Q. Al-awqati. 1985. Plasticity of functional polarity. Nature (Lond.). 318:368-571.

4. Sansom, S. C., E. J. Weinman, and R. G. O'Neil. 1984. Microelectrode assessment of chloride-conductive properties of cortical collecting duct. Am. J. Physiol. 247:F291-F203.

5. Koeppen, B. M., B. A. Biagi, and G. H. Giebisch. 1983. Intracellular microelectrode characterization of the rabbit cortical collecting duct. Am. J. Physiol. 244:F35-F47.
6. Brown, D., S. Hirsh, and S. Gluck. 1988. An $\mathrm{H}^{+}$-ATPase in opposite plasma domains in kidney epithelial cell subpopulations. Nature (Lond.). 331:622-624.

7. Muto, S., K. Yasoshima, K. Yoshitomi, M. Imai, and Y. Asano. 1990. Electrophysiological identification of $\alpha$ and $\beta$ intercalated cells and their distribution along the rabbit distal nephron segments. J. Clin. Invest. 86:1829-1839.

8. Furuya, H., M. D. Breyer, and H. R. Jacobson. 1991. Functional characterization of $\alpha$ and $\beta$ intercalated cell types in rabbit cortical collecting duct. Am.J. Physiol. 261:F377-F385.

9. Schuster, V. L., S. M. Bonsib, and M. L. Jennings. 1986. Two types of collecting duct mitochondria-rich (intercalated cells):lectin and band 3 cytochemistry. Am. J. Physiol. 251:C347-C355.

10. Wang, X., and I. Kurtz. 1990. $\mathrm{H}^{+} /$base transport in principal cells characterized by confocal fluorescence imaging. Am. J. Physiol. 259:C365-C373.

11. Emmons, C., K. Matsuzaki, J. B. Stokes, and V. L. Schuster. 1991. Axial heterogeneity of rabbit cortical collecting duct. Am. J. Physiol. 260:F498-F505.

12. Weiner, I. D., and L. L. Hamm. 1989. Use of fluorescent dye BCECF to measure intracellular pH in cortical collecting tubule. Am. J. Physiol. 256:F957F964.

13. LeHir, M., B. Kaissling, B. M. Koeppen, and J. B. Wade. 1982. Binding of peanut lectin to specific epithelial cell types in kidney. Am. J. Physiol. 244:F289F296.

14. Ridderstrale, Y., M. Kashgarian, B. Koeppen, G. Giebisch, D. Stetson, T. Ardito, and B. Stanton. 1988. Morphological heterogeneity of the rabbit collecting duct. Kidney Int. 34:655-670.

15. Alper, S. L., J. Natale, S. Gluck, H. F. Lodish, and D. Brown. 1989. Subtypes of intercalated cells in rat kidney collecting duct defined by antibodies against erythroid band 3 and renal vacuolar $\mathrm{H}^{+}$-ATPase. Proc. Natl. Acad. Sci. USA. 86:5229-5433.

16. Schuster, V. L., G. Fejes-Toth, A. Naray-Fejes-Toth, and S. Gluck. 1991. Colocalization of $\mathrm{H}^{+}$-ATPase and band 3 exchanger in rabbit collecting duct intercalated cells. Am. J. Physiol. 260:F506-517.

17. Bastani, B., H. Purcell, P. Hemken, D. Trigg, and S. Gluck. 1991. Expression and distribution of renal vacuolar proton-translocating adenosine triphosphatase in response to chronic acid and alkali loads in the rat. J. Clin. Invest. 88:126-136.

18. McKinney, T. D., and M. B. Burg. 1977. Bicarbonate transport by rabbit cortical collecting tubules. Effect of acid and alkali loads in vivo on transport in vitro. J. Clin. Invest. 60:766-768.

19. Satlin, L. M., and G. J. Schwartz. 1989. Cellular remodeling of $\mathrm{HCO}_{3}^{-}$ secreting cells in rabbit renal collecting duct in response to an acidic environment. J. Cell Biol. 109:1279-1288.

20. Schuster, V. L. 1985. Cyclic adenosine monophosphate-stimulated bicarbonate secretion in rabbit cortical collecting tubules. J. Clin. Invest. 75:29562064

21. Weiner, I. D., and L. L. Hamm. 1990. Regulation of intracellular pH in the rabbit cortical collecting tubule. J. Clin. Invest. 85:274-281.

22. Kim, J., C. C. Tisher, P. J. Linser, and K. M. Madsen. 1990. Ultrastructural localization of carbonic anhydrase II in subpopulations of intercalated cells of the rat kidney. J. Am. Soc. Nephrol. 1:245-256.

23. Satlin, L. M., and G. J. Schwartz. 1992. Adaptation of rabbit cortical collecting duct to in vitro acid incubation. Am. J. Physiol. 263:F749-F756.

24. Schuster, V. L., and J. B. Stokes. 1987. Chloride transport by the cortical and outer medullary collecting duct. Am. J. Physiol. 253:F203-F212.

25. Atherton, L. J., D. A. Maddox, F. J. Gennari, and W. M. Deen. 1988 Analysis of $\mathrm{pCO}_{2}$ variations in the renal cortex. I. Single nephron. Am. J. Physiol. 255:F349-F360.

26. Atherton, L. J., D. A. Maddox, F. J. Gennari, and W. M. Deen. 1988 Analysis of $\mathrm{pCO}_{2}$ variations in the renal cortex. II. Countercurrent exchange. $\mathrm{Am}$. J. Physiol. 255:F361-F371.

27. Stetson, D. L., and P. R. Steinmetz. 1985. $\alpha$ and $\beta$ types of carbonic anhydrase-rich cells in turtle bladder. Am. J. Physiol. 249:F553-F565.

28. Berry, C. A., and F. C. Rector, Jr. 1991. Mechanism of proximal NaCl reabsorption in the proximal tubule of the mammalian kidney. Semin. Nephrol. 11:86-97.

29. Schwartz, G. J., L. M. Satlin, and J. E. Bergmann. 1988. Fluorescent characterization of collecting duct cells: a second $\mathrm{H}^{+}$-secreting type. Am. J. Physiol. 255:F1003-1014. 